Article

\title{
Phytochemical Compounds as Cleaning Agents on Granite Colonized by Phototrophic Subaerial Biofilms
}

\author{
Chiara Genova ${ }^{1,2,3, *(\mathbb{C}}$, Elsa Fuentes ${ }^{1}$, Patricia Sanmartín ${ }^{1}\left(\mathbb{D}\right.$, Gabriele Favero ${ }^{3, *(\mathbb{C})}$ and \\ Beatriz Prieto ${ }^{1}$ (])
}

1 Departamento de Edafoloxía e Química Agrícola. Facultade de Farmacia, Universidade de Santiago de Compostela, 15782 Santiago de Compostela, Spain; elsa.fuentes.alonso@usc.es (E.F.); patricia.sanmartin@usc.es (P.S.); beatriz.prieto@usc.es (B.P.)

2 Department of Earth Science, Sapienza University of Rome; Piazzale Aldo Moro 5, 00185 Roma, Italy

3 Department of Chemistry and Drug Technologies, Sapienza University of Rome, Piazzale Aldo Moro 5, 00185 Roma, Italy

* Correspondence: chiara.genova@uniroma1.it (C.G.); gabriele.favero@uniroma1.it (G.F.); Tel.: +34-881814920 (C.G.); +39-06-4991-3669 (G.F.)

Received: 20 February 2020; Accepted: 19 March 2020; Published: 22 March 2020

\begin{abstract}
The society has become increasingly interested in using natural products over chemicals for cleaning activities. In this study, the cleaning potential of formulations embedded in a hydrogel matrix and composed respectively of essential oils (EOs) of Origanum vulgare, Thymus vulgaris, and Calamintha nepeta, and their respective main active components (EO-ACs), viz., Carvacrol, Thymol, and Pulegone, on a phototropic biofilm growing on granite was investigated. In addition, and for comparative purposes, analysis with the combination of the three EOs, the combination of the three EO-ACs, and Preventol RI- $80^{\circledR}$ (one of the most effective commercial cleaning agents based on quaternary ammonium salts) in all three cases embedded in a hydrogel matrix, as well as only the hydrogel matrix, distilled water, and Preventol RI- $80^{\circledR}$, in both latter cases applied with brush, were also studied. The cleaning effect of the treatments was assessed immediately after the treatment and after one and two weeks by color spectrophotometry, a reliable tool to evaluate the presence and vitality of the phototrophs and the cleaning effectiveness in granite. C. nepeta and its active component Pulegone proved to be the most effective and yielded similar results, comparable to those of uncolonized granite, and better than those obtained with Preventol RI- $80^{\circledR}$ applied with brush (most common way), especially at the end of the experiment. These promising first results support the suitable use of the phytochemical compounds used on phototrophs field where there are still few published studies and encourage further investigation toward the evaluation of their exhibited biocidal activity.
\end{abstract}

Keywords: essential oils (EOs); essential oil active components (EO-ACs); biodeterioration; granite; non-destructive techniques; algae; antibiofilm; green methods

\section{Introduction}

Because it has been estimated that from $20 \%$ to $30 \%$ of stone deterioration is a result of biological activity [1], it is clear that formation of subaerial biofilms, shortened to SABs and defined as "microbial communities that grow on solid surfaces exposed to the atmosphere" [2], represent an important topic for cultural conservation researchers. Many different methods, such as mechanical (brushing and rubbing, washing and steaming, wet and dry abrasives, etc.), physical (UV radiation, laser, etc.), chemical (alkaline and acidic treatments, organic solvents, etc.), and biological (viable bacterial cells, enzymes, etc.) have been employed to eliminate SABs-forming colonizing microorganisms from stone 
surfaces [3]. Cleaning of SABs is a necessary operation for conserving historical stone buildings, which generally is a very complicated procedure and involves a significant financial outlay. Chemical products are currently most practical and are employed for this purpose [4-6], although their use is not always encouraged on the basis of possible secondary implications on the environment and human health [7].

Furthermore, in the case of poultices with quaternary ammonium-based compounds (QACs), chemicals are largely employed in different fields because of their wide action for cleaning purposes (since, besides being antimicrobial agents, secondarily are used as surfactants) [8-10]. They can promote (as main side-effect) the recolonization of the surfaces by phototropic and heterotrophic microorganisms able to use the organic residuals of the QACs as carbon and nitrogen sources [1,11]. Indeed, in the study case of the Cave of Lascaux (France) it was demonstrated that the prolonged employment of a QACs derivate (benzalkonium chloride) to eliminate the fungus Fusarium solani from a subterranean mural painting increased the level of organic carbon content in the cave, with a consequent spread of other fungi (Ochroconis lascauxensis) and bacteria (Ralstonia spp. and Pseudomonas spp.) highly resistant to benzalkonium chloride and not originally detected on the surfaces $[12,13]$. Similarly, more recently, Urzì et al. [14] evidenced a recolonization by bacteria, with a drastic increase in their diversity, after a treatment with a mixture of quaternary ammonium compounds and octylisothiazolone (OIT) on hypogea environment.

A possible alternative to chemicals is represented by the use of essential oils (EOs): secondary metabolites produced by plants for the defense against pathogenic microorganisms and predators [15]. The increased interest in the use of these natural substances is partly attributable to their proved cleaning and biocidal properties at concentrations low enough to be harmless for the environment and human health [16]. The cleaning efficacy and biocide properties of some EOs on fungi and bacteria naturally present on stone materials have been established, also in comparison with some QACs based biocides. Stupar et al. [17] compared the minimal inhibitory concentration (MIC) of benzalkonium chloride and the essential oil of Origanum vulgare against four strains of fungi isolated from a mural painting (Aspergillus fumigatus, Aspergillus nidulans, Aspergillus versicolor, and Penicillium sp.). Essential oils rich in phenolic compounds such as carvacrol were reported to possess high levels of antimicrobial activity [18]. Other study of Stupar et al. [9] provided a similar test, employing three essential oils belonging to the Lamiaceae family (Lavandula angustifolia, Rosmarinus officinalis, and Origanum vulgare) and benzalkonium chloride in different concentrations against six fungi strains (Aspergillus niger Tiegh, Aspergillus ochrauceus G.Wilh, Penicillium Link sp., Thricoderma viride Pers., Bipolaris spicifera (Bainier) Subram, and Epicoccum nigrum Link). The lower MICs have been detected for O. vulgare and the QACs based biocide while L. angustifolia and R. officinalis showed a significantly lower antifungal activity. According to the authors [9], the different efficacies may be attributed to the composition of the EOs. Each EO was constituted by a mixture of 20 to 60 compounds but one or two of these, in greater proportion ( $20 \%-70 \%$ of the total composition), are the ones that establish the chemotype [15].

Phenolic compounds are one of the most important compounds in the EOs and are natural plant metabolites with different functions, among which their antimicrobial action stands out. The cleaning and biocidal efficacy of EOs with a predominantly phenolic composition have been demonstrated in the study of Mironescu et al. [19], where the fungicidal action of Thymus vulgaris, Thymus serpyllum and Foeniculum vulgare, mainly composed respectively by the monoterpenoids carvacrol, thymol, and estragol, was significantly greater than that attained by three EOs characterized by a predominant concentration of hydrocarbons.

Even if the bactericidal and fungicidal action of EOs has been demonstrated, few research deals with their potential use on photoautotrophic microorganisms (cyanobacteria and algae), i.e., pioneer colonizer of stone substrata [20]. Among those few studies, recently Bruno et al. [21] tested the efficacy of two EOs (Lavandula angustifolia and Thymus vulgaris), mixed together, against three commonly found cyanobacterial strains of subaerial biofilms detected in catacombs (Scytonema julianum, Oculatella subterranean, and Leptolyngbya sp.). The results showed that both concentrations 
used $(1 \%$ and $10 \%)$ inhibited the photosynthetic activities of the cyanobacteria, even if the mixture at $1 \%$ required two applications to make the biological activity undetectable.

In the present study, the cleaning potential of formulations embedded in a hydrogel matrix and composed respectively by Origanum vulgare, Thymus vulgaris, and Calamintha nepeta essential oils (EOs) and their respective main active components (EO-ACs), viz., Carvacrol, Thymol, and Pulegone were assessed on a phototropic biofilm growing on granite stone. The comparison of EOs versus EO-ACs, such as terpenic phenols (thymol and carvacrol) and terpenic ketone (pulegone) is very valuable to know if the effect of the latter is increased by being combined with other compounds present in the commercial oils. In addition, and for comparative purposes, analysis with the combination of the three EOs, the combination of the three EO-ACs, and Preventol RI- $80^{\circledR}$ in all three cases embedded in a hydrogel matrix, as well as only the hydrogel matrix, distilled water and Preventol RI- $80^{\circledR}$, in both latter cases applied with brush, were also analyzed. The cleaning effect of the treatments was assessed immediately after treatment and after one, and two weeks by color spectrophotometry.

In the context of this article, these treatments denote the cleaning effectiveness, i.e., removal of biofouling from granite surface, only removal not considering the microbial abatement related to biocide effect of treatment, intended to destroy, deter, or exert a controlling effect on organisms by chemical or biological means. In this sense, color spectrophotometry, the technique used in the study, allows to reliably evaluate the cleaning effectiveness in granite $[3,8]$.

\section{Materials and Methods}

\subsection{Granite Blocks Inoculated with Phototrophic Microorganisms}

The culture selected for the experimentation was already described in the study of Vázquez-Nion et al. [22]. This latter is mainly characterized by the presence of phototrophic microorganisms (green algae and cyanobacteria), in particular: Bracteacoccus minor (Schmidle ex Chodat) Petrová, Stichococcus bacillaris Nägeli, Chlorella sp., Isocystis sp., Aphanocapsa sp., Leptolyngbya cebennensis (Gomont) I.Umezaki and M.Watanabe. The culture was derived from a natural biofilm growing on a historic granitic building in Santiago de Compostela (Monastery of San Martiño Pinario, Santiago de Compostela, Spain) and demonstrated to be particularly suitable to reproduce a natural biofilm on granite stones in laboratory conditions, as the study of Vázquez-Nion et al. evidenced [23].

\subsection{Essential Oils and Their Main Active Compounds}

Three EOs of Origanum vulgare, Thymus vulgaris, and Calamintha nepeta were purchased from specialized retailers of natural phytochemical products. Oils of Origanum vulgare and Thymus vulgaris were purchased from Esencias Martínez Lozano (Murcia, Spain) and the oil of Calamintha nepeta from Joulienne Fauconnier (Corse, France). On the basis of their composition (Table 1), carvacrol, thymol, and pulegone were selected as the "active principles" (respectively carvacrol for O. vulgare, thymol for T. vulgaris, and pulegone for $C$. nepeta). The pure thymol ( $\geq 98.5 \%)$ carvacrol $(\geq 98 \%)$ and (R)-(+)-pulegone ( $\geq 90 \%$ ) compounds were purchased from Aldrich Corp. (St Louis, MO, USA). 
Table 1. Chemical characterization and chromatographic area percentage of the compounds present in the essential oils (EOs). Minor compounds (concentration $<0.02 \%$ ) have not been included. The concentrations in percentage of the active principles are indicated in bold.

\begin{tabular}{|c|c|c|c|}
\hline Compound. & C. nepeta & T. vulgaris ${ }^{1}$ & O. vulgare $^{1}$ \\
\hline$\alpha$-thujene & 0.1 & 1.3 & 1.3 \\
\hline$\alpha$-pinene & 1.1 & 0.9 & 0.9 \\
\hline Camphene & 0.04 & 1.0 & 0.1 \\
\hline Sabinene & 0.4 & - & - \\
\hline$\beta$-pinene & 1.1 & 0.3 & 0.1 \\
\hline 3-octanone & 0.1 & - & 0.3 \\
\hline$\beta$-mircene & 1.1 & 1.9 & 1.1 \\
\hline 3-octanol & 1.7 & - & - \\
\hline$\alpha$-phellandrene & 0.1 & 0.2 & 0.1 \\
\hline$\alpha$-terpinene & 0.3 & 1.6 & 0.7 \\
\hline p-cimene & 0.2 & 15.8 & 6.5 \\
\hline Limonene & 9.9 & 0.4 & 0.2 \\
\hline 1,8-cineole & 0.5 & 0.4 & 0.2 \\
\hline cis-b-ocimene & 0.2 & - & - \\
\hline trans-b-ocimene & 0.2 & - & - \\
\hline$\gamma$-terpinene & 0.5 & 10.2 & 5.9 \\
\hline $\begin{array}{l}\text { cis-sabinene } \\
\text { hydrate }\end{array}$ & 0.1 & - & - \\
\hline Terpinolene & 0.2 & 0.1 & 0.2 \\
\hline Linalool & 0.7 & 4.5 & 1.6 \\
\hline Camphor & 0.1 & 0.8 & - \\
\hline Menthone & 2.1 & 0.2 & - \\
\hline Isomenthone & 3.8 & - & - \\
\hline Borneol & - & 1.2 & 0.2 \\
\hline Menthol & 0.1 & - & - \\
\hline terpinene-4-ol & 3.1 & 1.4 & 0.6 \\
\hline$\alpha$-terpineol & 0.5 & 0.2 & 0.1 \\
\hline Verbenone & - & 0.2 & - \\
\hline Pulegone & 55.2 & - & - \\
\hline Piperitone & 0.6 & - & - \\
\hline Thymol & - & 46.4 & 3.8 \\
\hline Carvacrol & - & 4.0 & 70.5 \\
\hline Piperitenone & 10 & - & - \\
\hline piperitenone oxide & 0.4 & - & - \\
\hline$\alpha$-copaene & 0.1 & - & - \\
\hline$\beta$-bourbonene & 0.1 & - & - \\
\hline trans- $\beta$-caryophyllene & 0.5 & 2.0 & 2.0 \\
\hline germacrene D & 0.9 & - & - \\
\hline$\alpha$-humulene & 0.1 & - & 0.2 \\
\hline$\beta$-bisabolene & - & - & 0.3 \\
\hline$\gamma$-cadinene & 0.3 & 0.1 & - \\
\hline$\delta$-cadinene & 0.4 & 0.1 & - \\
\hline carophyllene oxyde & - & 0.2 & 0.2 \\
\hline
\end{tabular}

${ }^{1}$ Data provided by the producer (Esencias Martínez Lozano, Murcia, Spain).

\subsection{Experimental Setup}

The capacity of the essential oils (O. vulgare, T. vulgaris and C. nepeta) and their active principles (Carvacrol, Thymol, and Pulegone) as cleaning agents on phototrophs colonizing granite blocks was studied. For this purpose, twelve granite blocks $(5 \mathrm{~cm} \times 5 \mathrm{~cm} \times 2 \mathrm{~cm})$ were inoculated with $3 \mathrm{~mL}$ $\left(1.19 \mathrm{~g} \cdot \mathrm{L}^{-1}\right)$ of the previously described phototropic culture (Section 2.1) and maintained in controlled and stationary conditions of temperature $\left(23^{\circ} \mathrm{C}\right)$, relative humidity $(80 \%)$, and light $(12 \mathrm{~h} \mathrm{light} / \mathrm{dark}$ photoperiod) in a climatic chamber (SCLAB PGA-1228/2 HR) until biofilm formation (Figure 1). 


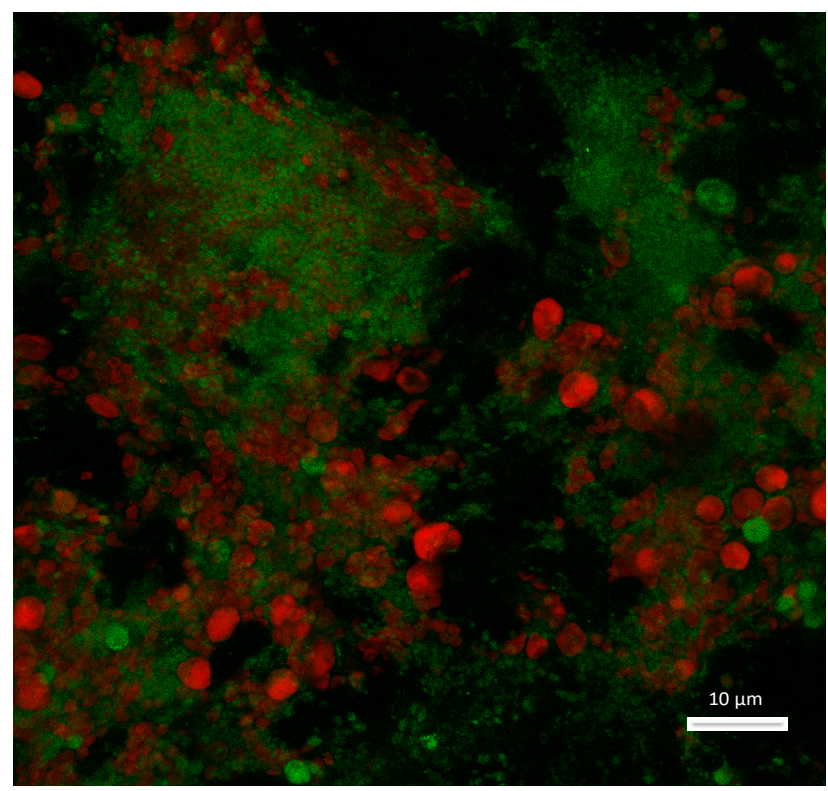

Figure 1. Confocal laser scanning microscopy (CLSM) imaging of the biofilm thrived on the granite surface. The red is the autofluorescence from the chlorophyll of the phototrophs, the green indicates the lipids stained with Lipidtox Green, and the grey is the reflection of the granite stone. Scale bar is $10 \mu \mathrm{m}$. A Leica TCS SP5 X CLSM (Leica Microsystems, Wetzlar, Germany) equipped with a white light laser and a $63 \mathrm{X}$ objective (NA 1.4, glycerol) was used to obtain the image.

When the granite samples showed the same level (or degree of presence) of biological colonization, each sample surface was divided into three replicate areas, each of ca. $1.7 \mathrm{~cm} \times 5 \mathrm{~cm}$, and different treatments were applied (Figure 2).

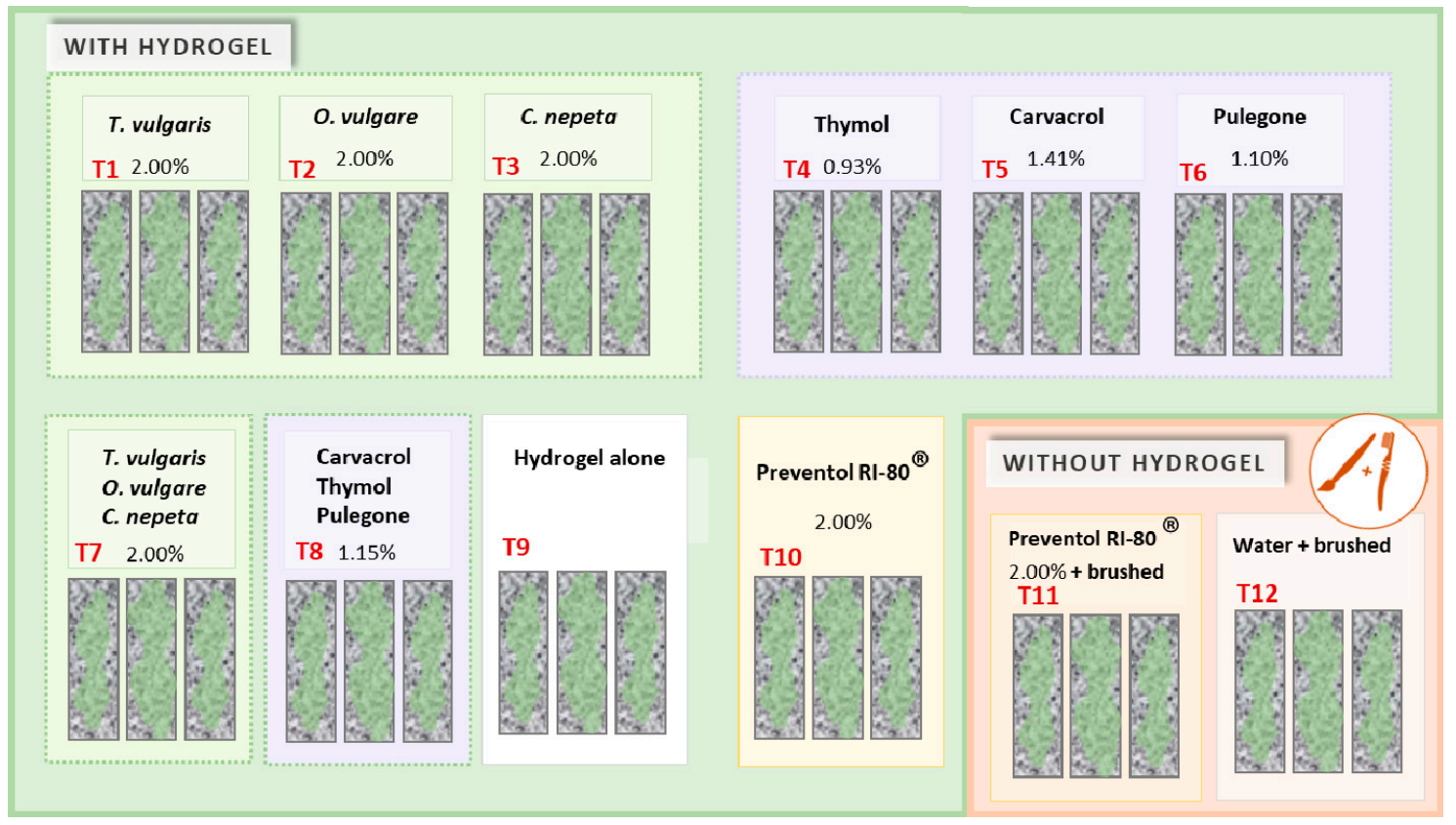

Figure 2. Schematic diagram of the experimental setup for testing the phytochemical compounds as cleaning agents.

The surfaces were treated with three commercial essential oils of the aromatic plants O. vulgare (T1), T. vulgaris (T2), and C. nepeta (T3), and the active principles present on the aforementioned plants: Carvacrol (T4), Thymol (T5), and Pulegone (T6). Furthermore, to evaluate an eventual synergic action 
between the substances and a consequent empowerment of their respective biocides properties, two additional emulsions were prepared mixing together the three essential oils (T7) and the three active components or phenolic compounds (T8). For the application, the products were incorporated inside an innovative hydrogel matrix conceived for the cleaning of cultural heritage materials, based on a mixture of surfactants and polymeric substances $(0.4 \% w / w$ Gelrite (Sigma-Aldrich, St. Louis, MO, USA), $4 \% w / w$ PVA (Sigma-Aldrich), $0.045 \% w / w \mathrm{CaCl}_{2}$, and $5 \% w / w$ Acemoll CC (ACEF, Fiorenzuola D'Arda (PC), Italy) dissolved in distilled water). The hydrogel matrix was also applied alone (T9) to determinate its own cleaning efficacy, enabling it to make a comparison when it is used alone or in combination with other substances. Finally, treatments with commercial biocide Preventol RI- $80^{\circledR}$, a well-known QAC that has given suitable results in cleaning of phototrophic biofilms [24], incorporated in the hydrogel matrix (T10) and applied with a brush (T11), and distilled water applied with a brush (T12) were included, for a total of 12 different treatments (Figure 2). An uncolonized clean granite sample was also incorporated as reference.

The concentration employed in the treatment emulsions containing the essential oils, alone (T1-T3) and combined (T7), and those containing Preventol RI- $80^{\circledR}$ (T10 and T11), was $2 \%(w / w)$ and $2 \%$ $(v / v)$ for T10 [25-28]. As already mentioned, the essential oils used in the study have as principal active component various phenolic compounds at certain concentrations. To investigate and establish the potential contribution of phenols in the biocidal action of oils, it was decided to use the same concentration of phenolic substances presents in the essential oils in the hydrogel emulsions (results reported in Table 1). For example, considering that $70.5 \%$ is the percentage of Carvacrol in O. vulgaris, the final concentration of the active substance in the emulsion with the hydrogel was $1.41 \%$ (T5 in Figure 2). The same was applied in the other cases: T4, T6, and T8 (Figure 2).

All treatments with hydrogel (from T1 to T10) were applied to the colonized surfaces with a paintbrush, left for a week until the hydrogel matrix dried completely, and then removed by peeling it off. In the cases without hydrogel, i.e., Preventol RI- $80^{\circledR}$ (in T11) and distilled water (T12) both treatments were applied with a paintbrush, allowed to dry, and then removed brushing the surface with a soft brush.

\subsection{Chemical Characterization of the Commercial Essential Oils (EOs)}

In the case of O. vulgare and T. vulgaris, both oils were acquired from the company Esencias Martínez Lozano, Murcia, Spain, which provided the chemical analyses and the relative data sheet containing the identified compounds at the respective concentrations (Table 1). C. nepeta oil was analyzed with a gas chromatography-mass spectrometry (GC-MS) system (Shimidazu, Kyoto, Japan) equipped with a MEGA SE52 5\% polydiphenyl-95\% dimethylsiloxane-bonded phase column (Mega, Legnano, Italy) (dim. $30 \mathrm{~m} \times 0.32 \mathrm{~mm} \times 0.15 \mu \mathrm{m})$. The oven temperature used was initially $50{ }^{\circ} \mathrm{C}$ heating to $250^{\circ} \mathrm{C}$ at a rate of $3{ }^{\circ} \mathrm{C} / \mathrm{min}$. The operating conditions were: injection temperature $250{ }^{\circ} \mathrm{C}$, carrier (helium) flow rate of $1 \mathrm{~mL} / \mathrm{min}$, electronic impact mode of $70 \mathrm{eV}$, injection in the split mode, interface at $230{ }^{\circ} \mathrm{C}$, quadrupole temperature $150^{\circ} \mathrm{C}$, transfer line temperature $280^{\circ} \mathrm{C}$, SCAN acquisition mode (masses interval: 35-350 AMU). For the analyses, the oil extracts were diluted in cyclohexane $(5 \mathrm{mg} / \mathrm{mL}$ ). The identification of the compounds was realized by comparing the mass spectra reported in the commercial libraries and using the retention indexes compared with those of the reference libraries [29].

\subsection{Evaluation of Cleaning Effectiveness by Using Color Spectrophotometry Analysis}

The cleaning effect of the treatments was assessed immediately after treatment, and after one and two weeks, by color spectrophotometry, a reliable tool to evaluate the presence and vitality of phototrophs [30-35] and the cleaning effectiveness in granite [8,24].

A portable spectrophotometer (CM-700d, Konica Minolta, Tokyo, Japan) equipped with a CM-S100w software (SpectraMagic ${ }^{\mathrm{TM}} \mathrm{NX}$ ) was used for instrumental color measurements, under the 
following analytical conditions: D65 illuminant, $2^{\circ}$ observer, target area of $8 \mathrm{~mm} ø$ and SCI mode. Three measurements were made in each replicate area, i.e., nine measurements by each treatment.

Color was measured directly on randomly selected areas of the humid colonized surfaces [36]: before cleaning, immediately after cleaning, one week after cleaning, and two weeks after cleaning. Monitorization for 14 days was carried out in order to evaluate the effectiveness and persistence of each treatment over time in terms of cleaning, and to evaluate the change of color of the substrate over time. The data were analyzed using the CIELAB color system [37], where of the three parameters $\left(\mathrm{L}^{*}, \mathrm{a}^{*}\right.$ and $\mathrm{b}^{*}$ ) that define it, only the chromatic parameters, i.e., $\mathrm{a}^{*}$ (associated with changes in redness-greenness) and $\mathrm{b}^{*}$ (associated with changes in yellowness-blueness) proved relevant for evaluating the efficacy of the treatments, as in Sanmartín et al. [8,24]. Thus, partial differences in these parameters were determined using the following equations:

$$
\begin{aligned}
& \Delta \mathrm{a}^{*}=\mathrm{a}^{*}{ }_{\mathrm{i}}-\mathrm{a}^{*}{ }_{0} \\
& \Delta \mathrm{b}^{*}=\mathrm{b}^{*}{ }_{\mathrm{i}}-\mathrm{b}^{*}{ }_{0}
\end{aligned}
$$

where the subscript $i$ denotes the average value of the parameter immediately after, one or two weeks after the cleaning procedure, and the subscript 0 denotes the average value of parameter before the application of the treatments. Positive values of $\Delta \mathrm{a}^{*}$ indicate reddening, and negative values indicate greening. Positive values of $\Delta \mathrm{b}^{*}$ indicate yellowing, and negative values indicate blueing.

\subsection{Statistical Analysis}

The data were subjected to analysis of variance (ANOVA) and Tukey's HSD post-hoc test ( $p$-value $\leq 0.05)$ implemented in the SPSS statistical program (version 23.0).

\section{Results and Discussion}

\subsection{Essential Oils (EOs) Content and Chemical Composition}

The chemical compositions of the essential oils (C. nepeta, T. vulgaris, O. vulgare) are detailed in Table 1. A total of 36 compounds have been identified in C. nepeta ( $96.8 \%$ of the total composition), 25 compounds in T. vulgaris ( $95.3 \%$ of the total composition) and 23 compounds in O. vulgare ( $96.7 \%$ of the total composition). The presence of the major phenolic compounds in each oil (i.e., active principles) have been confirmed, where Pulegone represents the $55.2 \%$ of the total composition of C. nepeta, thymol the $46.4 \%$ of $T$. vulgaris and carvacrol the $70.5 \%$ of $O$. vulgare. The presence of Carvacrol ( $4 \%$ ) has been detected also in T. vulgaris, as well as thymol (3.8\%) in O. vulgare.

\subsection{Cleaning Effectiveness of the Treatments}

In all cases, a single application of the treatment successfully removed much of the subaerial biofilm, as assessed by naked eye observation (Figure 3). After cleaning, main visual changes were observed in T3, T6, T9, T11, and T12; two weeks after cleaning T4 and T7 were added to the list (Figure 3).

Before cleaning, chromatic color data from all samples were included in a small color gamut, ranging between -5.0 and -3.0 CIELAB units for $\mathrm{a}^{*}$, and between 18.1 and 15.3 CIELAB units for $\mathrm{b}^{*}$ (Figure 4). They can be considered similar starting points according to colorimetric criteria and considering the upper limit of rigorous color tolerance or noticeable change in color of three CIELAB units [38,39]. 


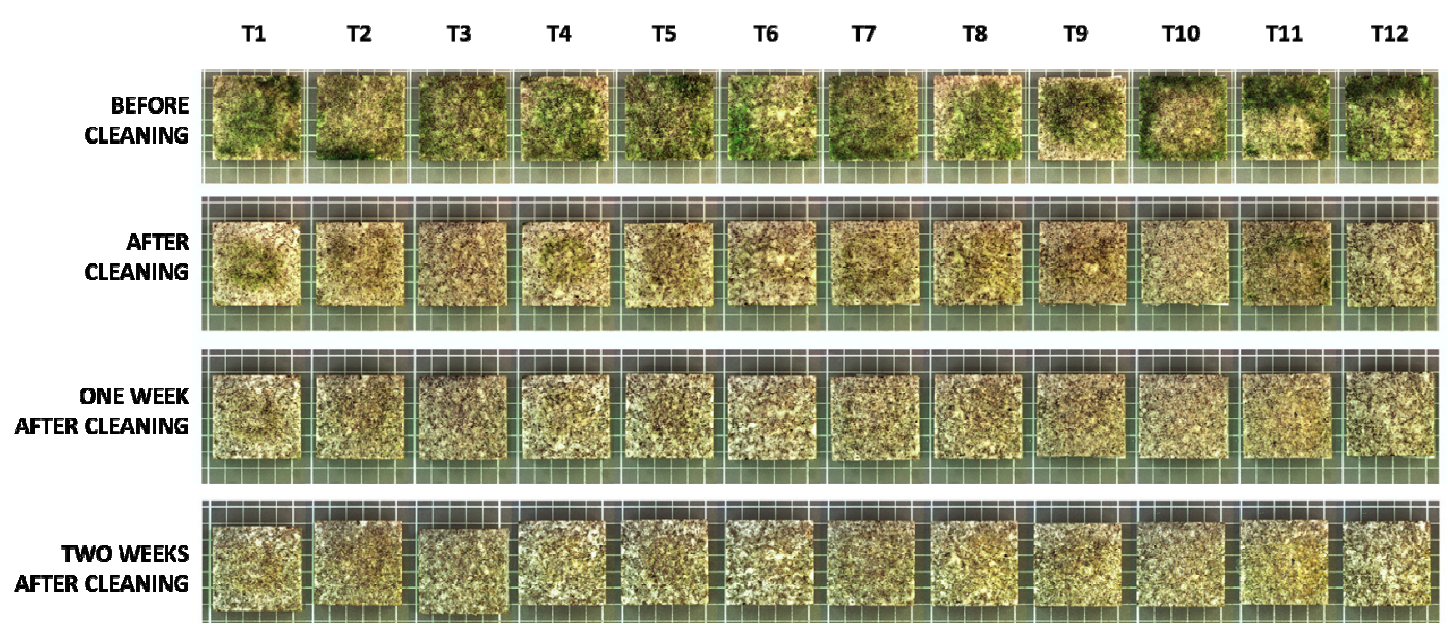

Figure 3. Macroscopic appearance of the samples studied throughout the experimental period.

As seen in Figure 4 and Table 2, after cleaning all treatments led to changes toward red (marked by an increase in the coordinate $\mathrm{a}^{*}$ and positive values of $\Delta \mathrm{a}^{*}$ ) and blue (marked by a decrease in the coordinate $\mathrm{b}^{*}$ and negative values of $\Delta \mathrm{b}^{*}$ ) components. This trend continued until the end of the experiment, and increased with time. Thus, two weeks after cleaning the chromatic values are close to the reference value indicated by an uncolonized clean granite sample (Figure 4). It demonstrated that the changes were associated with the effective cleaning during the experiment and not with a change in color of the granite substrate. In this regard, it also indicates that observing the more consistent variations of $\Delta \mathrm{b}^{*}$, it seems that this coordinate was more informative for the purpose of the study, in line with previous studies of phototrophic biofilms on granite rocks [33].

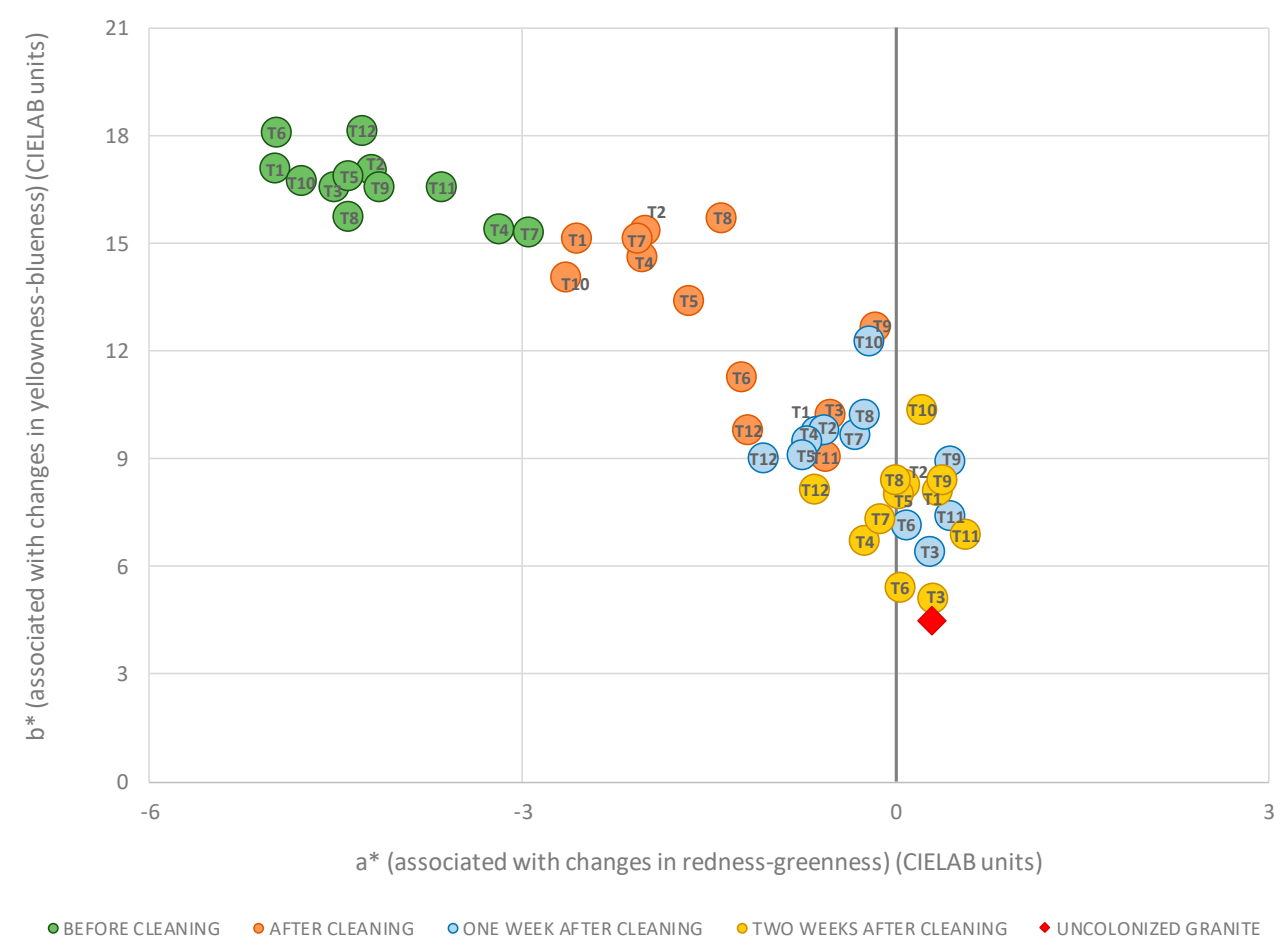

Figure 4. Color changes of the samples studied throughout the experimental period in the $b^{*}$ versus $a^{*}$ diagram. Each symbol is also identified by a sub-legend showing the sample's treatment (codes are shown in Figure 2). 
Table 2. Changes in the green-red color component $\left(\Delta \mathrm{a}^{*}\right)$ and blue-yellow color component $\left(\Delta \mathrm{b}^{*}\right)$ in the treated samples throughout the study period. Different superscript letters in each row indicate significant differences $(p \leq 0.05)$ in relation to the different stages of the sample's treatment for a given partial color difference.

\begin{tabular}{|c|c|c|c|c|c|c|c|}
\hline \multirow[b]{2}{*}{ Treatment } & \multirow[b]{2}{*}{ Components } & \multicolumn{3}{|c|}{$\Delta \mathbf{a}^{*}$ (CIELAB Units) } & \multicolumn{3}{|c|}{$\Delta \mathrm{b}^{*}$ (CIELAB Units) } \\
\hline & & $\begin{array}{c}\text { After } \\
\text { Cleaning }\end{array}$ & $\begin{array}{c}\text { One Week } \\
\text { after } \\
\text { Cleaning }\end{array}$ & $\begin{array}{c}\text { Two Weeks } \\
\text { after } \\
\text { Cleaning }\end{array}$ & $\begin{array}{c}\text { After } \\
\text { Cleaning }\end{array}$ & $\begin{array}{c}\text { One Week } \\
\text { after } \\
\text { Cleaning }\end{array}$ & $\begin{array}{c}\text { Two Weeks } \\
\text { after } \\
\text { Cleaning }\end{array}$ \\
\hline T1 & T. vulgaris & $2.4^{\mathrm{A}}$ & $4.4^{\mathrm{B}}$ & $5.3^{\mathrm{B}}$ & $-2.0^{\mathrm{A}}$ & $-7.3^{\mathrm{B}}$ & $-9.0^{\mathrm{B}}$ \\
\hline T2 & O. vulgare & $2.2^{\mathrm{A}}$ & $3.6^{\mathrm{B}}$ & $4.3^{\mathrm{C}}$ & $-1.7^{\mathrm{A}}$ & $-7.3^{\mathrm{B}}$ & $-8.8^{\mathrm{B}}$ \\
\hline T3 & C. nepeta & $4.0^{\mathrm{A}}$ & $4.8^{\mathrm{A}}$ & $4.8^{\mathrm{A}}$ & $-6.3^{\mathrm{A}}$ & $-10.1^{\mathrm{B}}$ & $-11.5^{\mathrm{B}}$ \\
\hline $\mathrm{T} 4$ & Thymol & $1.2^{\mathrm{A}}$ & $2.5^{\mathrm{B}}$ & $2.9^{\mathrm{B}}$ & $-0.8^{\mathrm{A}}$ & $-5.9^{\mathrm{B}}$ & $-8.7^{\mathrm{B}}$ \\
\hline T5 & Carvacrol & $2.7^{\mathrm{A}}$ & $3.6^{\mathrm{AB}}$ & $4.4^{\mathrm{B}}$ & $-3.5^{\mathrm{A}}$ & $-7.8^{\mathrm{B}}$ & $-8.9^{\mathrm{B}}$ \\
\hline T6 & Pulegone & $3.7^{\mathrm{A}}$ & $5.1^{\mathrm{B}}$ & $5.0^{\mathrm{B}}$ & $-6.8^{\mathrm{A}}$ & $-10.9^{\mathrm{B}}$ & $-12.7^{\mathrm{B}}$ \\
\hline T7 & All EOs & $0.9^{\mathrm{A}}$ & $2.6^{\mathrm{B}}$ & $2.8^{\mathrm{B}}$ & $-0.2^{\mathrm{A}}$ & $-5.6^{\mathrm{B}}$ & $-8.0^{\mathrm{C}}$ \\
\hline T8 & All APs & $3.0^{\mathrm{A}}$ & $4.1^{\mathrm{B}}$ & $4.4^{\mathrm{B}}$ & $0.0^{\mathrm{A}}$ & $-5.5^{\mathrm{B}}$ & $-7.3^{\mathrm{C}}$ \\
\hline T9 & Hydrogel & $4.0^{\mathrm{A}}$ & $4.6^{\mathrm{B}}$ & $4.5^{\mathrm{B}}$ & $-3.9^{\mathrm{A}}$ & $-7.6^{\mathrm{B}}$ & $-8.2^{\mathrm{B}}$ \\
\hline T10 & $\begin{array}{c}\text { Preventol + } \\
\text { Hydrogel }\end{array}$ & $2.1^{\mathrm{A}}$ & $4.6^{\mathrm{B}}$ & $5.0^{\mathrm{B}}$ & $-2.7^{\mathrm{A}}$ & $-4.4^{\mathrm{AB}}$ & $-6.3^{\mathrm{B}}$ \\
\hline T11 & Preventol & $3.1^{\mathrm{A}}$ & $4.1^{\mathrm{B}}$ & $4.2^{\mathrm{B}}$ & $-7.5^{\mathrm{A}}$ & $-9.2^{\mathrm{B}}$ & $-9.7^{\mathrm{B}}$ \\
\hline T12 & Water & $3.1^{\mathrm{A}}$ & $3.2^{\mathrm{A}}$ & $3.6^{\mathrm{A}}$ & $-8.4^{\mathrm{A}}$ & $-9.1^{\mathrm{A}}$ & $-10.0^{\mathrm{A}}$ \\
\hline
\end{tabular}

Taking into account both chromatic coordinates, the treatments that provoked significant color changes after their application were T3, T5, T6, T9, T10, T11, and T12 (data not shown), while those that exceeded the threshold of 3 CIELAB units in both partial differences $\Delta \mathrm{a}^{*}$ and $\Delta \mathrm{b}^{*}$ were T3, T6, T9, T11, and T12 (Table 2). These results are consistent with those reported by naked eye observation (Figure 3).

In $\mathrm{T} 6, \mathrm{~T} 9$, and T11 there were significant changes in values of $\Delta \mathrm{a}^{*}$ (increasing) and $\Delta \mathrm{b}^{*}$ (decreasing) between immediately after treatment and one week later, and in the case of T3 it was only in $\Delta \mathrm{b}^{*}$ (Table 2). It shows that after cleaning, these four treatments left some organism alive over the surface of the stone, whose color after one week turned from pale green to yellow and then bleached due to the senescence and death of the cells and the concomitant degradation of chlorophyll-a content $[32,33,36]$.

At the end of the experiment, all treatments achieved values of $\mathrm{a}^{*}$ ranging between -0.7 and 0.6 CIELAB units, very close to the reference $a^{*}$ value of the uncolonized granite of 0.3 CIELAB units (Figure 4). In the case of $b^{*}$, the values ranged between 10.4 and 5.1 CIELAB units, with a reference value of 5.2 CIELAB units (Figure 4), allowing to use this coordinate to make differences between the treatments' success, in line with the above mentioned. Accordingly, T3 and T6 obtained a value practically identical to that of the reference, with values of $b^{*}$ of 5.1 and 5.4 CIELAB units respectively, yielded therefore the best results. This resulted in the end of study, not continuing it over time. T4, T11, $\mathrm{T} 7, \mathrm{~T} 5$, and $\mathrm{T} 1$ produced results of $\mathrm{b}^{*}$ away from reference value in 1.5, 1.7, 2.1, 2.8, and 2.9 CIELAB units, all below the previously indicated visual threshold of 3 CIELAB units. The other treatments, i.e., $\mathrm{T} 12, \mathrm{~T} 2, \mathrm{~T} 8$, and $\mathrm{T} 9$, with $\mathrm{b}^{*}$ values ranged between 8.2 and $8.4 \mathrm{CELAB}$ units, barely exceeding this threshold; whereas T10 reached a partial difference of $b^{*}$ with respect to the reference of 5.2 CIELAB units (> 5 CIELAB units, the normal limit of perception in industrial or technical applications $[38,40])$.

Pulegone (T6) is the main component of $C$. nepeta oil (T3), so the most effectiveness of both treatments in the cleaning should be attributed to this terpenic ketone, which seems to be effective either applied individually or incorporated in an oil product. For visual comparative purposes, these results can also be observed in Figure 5. A previous study where the essential oil active components (EO-ACs): limonene, menthone, pulegone, and menthol were tested against the bacteria Listeria monocytogenes, Bacillus cereus, Salmonella veneziana, S. paratyphi B, and S. typhimurium, and the fungi Fusarium moniliforme, Botrytis ÿinereal, Aspergillus niger, and Pyricularia oryzae, using the agar diffusion technique, showed also that only pulegone had an effective response regarding the antimicrobial activity, particularly against the Salmonella species [39]. Preventol RI-80 ${ }^{\circledR}$ embedded in a hydrogel matrix (T10), on the contrary, was the least effective cleaning treatment of the twelve tested, but not its two components separately, Preventol RI- $80^{\circledR}$ applied with a brush (T11) and hydrogel (T9). 
It could be due to an incompatibility of both compounds when mixed, i.e., they are more effective separately than together, which impedes the effective action. Similarly, the treatments where the three essential oils were combined (T7) and, to a greater extent, where the three active compounds were combined (T8) yielded rather poor results, similar to T. vulgaris (T1) and O. vulgare (T2) oils separately, and their active components Thymol (T4) and Carvacrol (T5) also separately, which indicated that the effect of C. nepeta (T3) and Pulegone (T6) in the mixture, is either neutralized or turns out to be in an excessively low percentage to achieve a successful effect. However, in a previous study by Bruno et al. [21] the application of a combination of essential oils from L. angustifolia and T. vulgaris was effective in killing phototrophic biofilms also at low concentrations. Also, O. vulgare proved, in a previous study [9], to be the most effective, compared to L. angustifolia and R. offocinalis, with regards to antifungal properties, using Epicoccum nigrum and Bipolaris spicifera as test species, with comparable results to those obtained with the commercial biocide QACs derivate benzalkonium chloride.
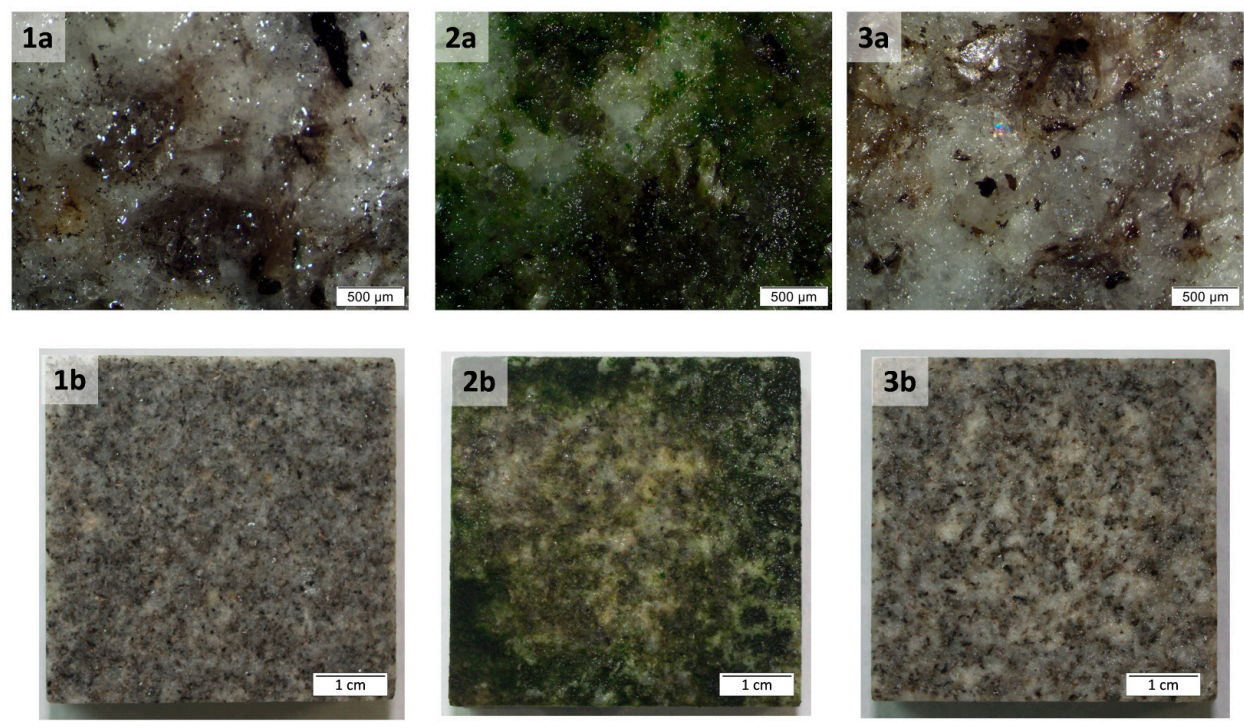

Figure 5. Granite samples (a) examined under a stereoscopic microscope Nikon Eclipse E600, Tokyo, Japan. Scale bar is $500 \mu \mathrm{m}$. (b) photographed with a macro lens Tamron SP 90mm F/2.8 Di MACRO 1:1. Scale bar is $1 \mathrm{~cm}$. (1) Uncolonized, (2) colonized, (3) cleaned with C. Nepeta (T3).

It is well-known that essential oils are widely used in various industries. However, it should be remembered that the chemical composition of the EOs and the content of bioactive compounds are variable, even when they come from the same plants. Differences in composition of the EOs may affect its effectiveness and may be variable. Also, it is possible to suppose that the efficacy of essential oils is closely related with the ratio of the active components in their composition, whereas the efficacy of essential oils and essential oil active components are related with the target microorganisms. As an example, C. nepeta of autochthonous aromatic plants from Alentejo (Portugal) demonstrated high toxicity against Artemia salina shrimp larvae and presented higher content in oxygenated monoterpenes, with 1,8-cineole as main component [41], while in our study 1,8-cineole was found at a concentration of barely $0.5 \%$ (Table 1 ).

\section{Conclusions}

In general, the results obtained for the essentials oils (both alone and combined) are comparable with those of their respective major terpenic compounds. This confirms the high contribution in the biocidal action of the major compound (i.e., active principle) in the heterogeneous composition of the essential oil. This result is encouraging in view of possible future experimentations that will provide the employment of the active principles alone, which presents advantages as: (i) formulation of $a d$ hoc treatments with simpler product combinations and (ii) lower treatment costs. 
C. nepeta and its active component Pulegone yielded similar results, comparable to those of uncolonized-clean granite, proving to be the most effective treatment, even better than application of Preventol RI- $80^{\circledR}$ plus brushing (most common treatment at present).

The efficacy of the phytochemicals on the target microorganism seems to depend on their chemical composition. This matter must be investigated deeply in order to create treatments containing single or mixtures of products against a specific, characterized biofilm.

To investigate the biocidal properties of these EOs, and not only the cleaning ones, future studies should involve re-inoculating the treated samples with the same phototropic culture to determine if the presence of the eventual residual compounds may influence the growth of the microorganisms.

Finally, it is worth indicating that it is the first study where phytochemical compounds are embedded in a hydrogel matrix and applied on phototrophic subaerial biofilms. This innovative mode of application, which uses harmless gel with high adhesive properties, avoids the deleterious effect of brushing on surface stone.

Author Contributions: Conceptualization, C.G., G.F., and B.P.; methodology, C.G., E.F., and B.P.; validation, C.G., E.F., P.S., and B.P.; laboratory work, C.G. and E.F.; resources, B.P.; writing-original draft preparation, C.G., E.F., and P.S.; writing - review and editing, C.G., E.F., P.S., G.F., and B.P.; supervision, B.P.; project administration, G.F. and B.P.; funding acquisition, G.F. and B.P. All authors have read and agreed to the published version of the manuscript.

Funding: This study was partly funded by projects ED431C 2018/32 and CGL2016-79778-R AEI/FEDER, UE. E. Fuentes is supported by a PhD Fellowship-Contract MICINN-FPI (BES-2017-079927).

Acknowledgments: The authors are grateful to P. Matricardi (Sapienza University of Rome, Rome, Italy) and C. Cencetti (QI technologies s.r.l, Pomezia (RM), Italy) for the ideation of the hydrogel and QI technologies s.r.l. for making available the hydrogel itself and the materials necessary for its realization. Thanks to Paula Castiñeiras for assistance in the laboratory and other activities, and Carlo Bicchi and Barbara Sgorbini (Università degli Studi di Torino, Turin, Italy) for kindly providing data of the chemical characterization of C. nepeta essential oil.

Conflicts of Interest: The authors declare no conflict of interest.

\section{References}

1. Wakefield, R.D.; Jones, M.S. An introduction to stone colonizing micro-organisms and biodeterioration of building stone. Q. J. Eng. Geol. Hydrogeol. 1998, 31, 301-313. [CrossRef]

2. Gorbushina, A.A. Life on the rocks. Environ. Microbiol. 2007, 9, 1613-1631. [CrossRef] [PubMed]

3. Sanmartín, P.; DeAraujo, A.; Vasanthakumar, A. Melding the old with the new: Trends in methods used to identify, monitor, and control microorganisms on cultural heritage materials. Microb. Ecol. 2018, 76, 64-80. [CrossRef] [PubMed]

4. Bosch-Roig, P.; Lustrato, G.; Zanardini, E.; Ranalli, G. Biocleaning of cultural heritage stone surfaces and frescoes: Which delivery system can be the most appropriate? Ann. Microbiol. 2015, 65, 1227-1241. [CrossRef]

5. Kakakhel, M.A.; Wu, F.; Gu, J.D.; Feng, H.; Shah, K.; Wang, W. Controlling biodeterioration of cultural heritage objects with biocides: A review. Int. Biodeterior. Biodegrad. 2019, 143, 104721. [CrossRef]

6. Fidanza, M.R.; Caneva, G. Natural biocides for the conservation of stone cultural heritage: A review. J. Cult. Herit. 2019, 38, 271-286. [CrossRef]

7. Toreno, G.; Isola, D.; Meloni, P.; Carcangiu, G.; Selbmann, L.; Onofri, S.; Caneva, G.; Zucconi, L. Biological colonization on stone monuments: A new low impact cleaning method. J. Cult. Herit. 2018, 30, 100-109. [CrossRef]

8. Pozo-Antonio, J.S.; Montojo, C.; López de Silanes, M.E.; de Rosario, I.; Rivas, T. In situ evaluation by colour spectrophotometry of cleaning and protective treatments in granitic cultural heritage. Int. Biodeterior. Biodegrad. 2017, 123, 251-261. [CrossRef]

9. Stupar, M.; Grbić, M.L.; Džamić, A.; Unković, N.; Ristić, M.; Jelikić, A.; Vukojević, J. Antifungal activity of selected essential oils and biocide benzalkonium chloride against the fungi isolated from cultural heritage objects. S. Afr. J. Bot. 2014, 93, 118-124. [CrossRef]

10. Bartolini, M.; Pietrini, A.; Ricci, S. Valutazione dell'efficacia di alcuni nuovi biocidi per il trattamento di microflora fotosintetica e di briofite su materiali lapidei. Boll. ICR—Nuova Ser. 2007, 14, 101-111. (In Italian) 
11. Patrauchan, M.A.; Oriel, P.J. Degradation of benzyldimethylalkylammonium chloride by Aeromonas hydrophila sp. K. J. Appl. Microbiol. 2003, 94, 266-272. [CrossRef]

12. Bastian, F.; Alabouvette, C.; Jurado, V.; Saiz-Jimenez, C. Impact of biocide treatments on the bacterial communities of the Lascaux Cave. Naturwissenschaften 2009, 96, 863-868. [CrossRef]

13. Martin-Sanchez, P.M.; Nováková, A.; Bastian, F.; Alabouvette, C.; Saiz-Jimenez, C. Use of biocides for the control of fungal outbreaks in subterranean environments: The case of the Lascaux cave in France. Environ. Sci. Technol. 2012, 46, 3762-3770. [CrossRef]

14. Urzì, C.; De Leo, F.; Krakova, L.; Pangallo, D.; Bruno, L. Effects of biocide treatments on the biofilm community in Domitilla's catacombs in Rome. Sci. Total Environ. 2016, 572, 252-262. [CrossRef]

15. Bakkali, F.; Averbeck, S.; Averbeck, D.; Idaomar, M. Biological effects of essential oils-A review. Food Chem. Toxicol. 2008, 46, 446-475. [CrossRef]

16. Saxena, J.; Mathela, C.S. Antifungal activity of new compounds from Nepeta leucophylla and Nepeta clarkei. Appl. Environ. Microbiol. 1996, 62, 702-704. [CrossRef]

17. Stupar, M.; Grbić, M.L.; Simić, G.S.; Jelikić, A.; Vukojević, J.; Sabovljević, M. A sub-aerial biofilms investigation and new approach in biocide application in cultural heritage conservation: Holy Virgin Church (Gradac Monastery, Serbia). Indoor Built Environ. 2014, 23, 584-593. [CrossRef]

18. Aligiannis, N.; Kalpoutzakis, E.; Mitaku, S.; Chinou, I.B. Composition and antimicrobial activity of the essential oils of two Origanum species. J. Agric. Food Chem. 2001, 49, 4168-4170. [CrossRef]

19. Mironescu, M. Activity of some essential oils against common spoilage fungi of buildings. Acta Univ. Cibiniensis Ser. E Food Technol. 2010, XIV, 41-46.

20. Grant, C. Fouling of terrestrial substrates by algae and implications for control-A review. Int. Biodeterior. Bull. 1982, 18, 57-65.

21. Bruno, L.; Rugnini, L.; Spizzichino, V.; Caneve, L.; Canini, A.; Ellwood, N.T.W. Biodeterioration of Roman hypogea: The case study of the Catacombs of SS. Marcellino and Pietro (Rome, Italy). Ann. Microbiol. 2019, 69, 1023-1032. [CrossRef]

22. Vázquez-Nion, D.; Rodríguez-Castro, J.; López-Rodríguez, M.C.; Fernández-Silva, I.; Prieto, B. Subaerial biofilms on granitic historic buildings: Microbial diversity and development of phototrophic multi-species cultures. Biofouling 2016, 32, 657-669. [CrossRef]

23. Vázquez-Nion, D.; Silva, B.; Troiano, F.; Prieto, B. Laboratory grown subaerial biofilms on granite: Application to the study of bioreceptivity. Biofouling 2017, 33, 24-35. [CrossRef]

24. Sanmartín, P.; Rodríguez, A.; Aguiar, U. Medium-term field evaluation of several widely used cleaning-restoration techniques applied to algal biofilm formed on a granite-built historical monument. Int. Biodeterior. Biodegrad. 2020, 147, 104870. [CrossRef]

25. Favero-Longo, S.E.; Benesperi, R.; Bertuzzi, S.; Bianchi, E.; Buffa, G.; Giordani, P.; Loppi, S.; Malaspina, P.; Matteucci, E.; Paoli, L.; et al. Species- and site-specific efficacy of commercial biocides and application solvents against lichens. Int. Biodeterior. Biodegrad. 2017, 123, 127-137. [CrossRef]

26. Coutinho, M.L.; Miller, A.Z.; Martin-Sanchez, P.M.; Mirão, J.; Gomez-Bolea, A.; Machado-Moreira, B.; Cerqueira-Alves, L.; Jurado, V.; Saiz-Jimenez, C.; Lima, A.; et al. A multiproxy approach to evaluate biocidal treatments on biodeteriorated majolica glazed tiles. Environ. Microbiol. 2016, 18, 4794-4816. [CrossRef]

27. Vannini, A.; Contardo, T.; Paoli, L.; Scattoni, M.; Favero-Longo, S.E.; Loppi, S. Application of commercial biocides to lichens: Does a physiological recovery occur over time? Int. Biodeterior. Biodegrad. 2018, 129, 189-194. [CrossRef]

28. Hammer, K.A.; Carson, C.F.; Riley, T.V. Antimicrobial activity of essential oils and other plant extracts. J. Appl. Microbiol. 1999, 86, 985-990. [CrossRef]

29. Adams, R.P. Identification of Essential Oil Components by Gas Chromatography/Mass Spectrometry, 4th ed.; Adams, R.P., Ed.; Allured Publishing Corporation: Carol Stream, IL, USA, 2007; ISBN 9781932633214.

30. Prieto, B.; Rivas, T.; Silva, B. Rapid quantification of phototrophic microorganisms and their physiological state through their colour. Biofouling 2002, 18, 229-236. [CrossRef]

31. Sanmartin, P.; Aira, N.; Devesa-Rey, R.; Silva, B.; Prieto, B. Relationship between color and pigment production in two stone biofilm-forming cyanobacteria (nostoc sp. pcc 9104 and nostoc sp. pcc 9025). Biofouling 2010, 26, 499-509. [CrossRef] 
32. Sanmartín, P.; Villa, F.; Polo, A.; Silva, B.; Prieto, B.; Cappitelli, F. Rapid evaluation of three biocide treatments against the cyanobacterium Nostoc sp. PCC 9104 by color changes. Ann. Microbiol. 2015, 65, 1153-1158. [CrossRef]

33. Sanmartín, P.; Vázquez-Nion, D.; Silva, B.; Prieto, B. Spectrophotometric color measurement for early detection and monitoring of greening on granite buildings. Biofouling 2012, 28, 329-338. [CrossRef]

34. Sanmartín, P.; Fuentes, E.; Montojo, C.; Barreiro, P.; Paz-Bermúdez, G.; Prieto, B. Tertiary bioreceptivity of schists from prehistoric rock art sites in the Côa Valley (Portugal)and Siega Verde (Spain)archaeological parks: Effects of cleaning treatments. Int. Biodeterior. Biodegrad. 2019, 142, 151-159. [CrossRef]

35. Prieto, B.; Vázquez-Nion, D.; Fuentes, E.; Durán-Román, A.G. Response of subaerial biofilms growing on stone-built cultural heritage to changing water regime and $\mathrm{CO}_{2}$ conditions. Int. Biodeterior. Biodegrad. 2020, 148, 104882. [CrossRef]

36. Prieto, B.; Sanmartín, P.; Aira, N.; Silva, B. Color of cyanobacteria: Some methodological aspects. Appl. Opt. 2010, 49, 2022-2029. [CrossRef]

37. CIE. Colorimetrie, 2nd ed.; Central Bureau of the Commission International de L'Eclairage: Viena, Austria, 1986.

38. Sanmartín, P.; Chorro, E.; Vázquez-Nion, D.; Martínez-Verdú, F.M.; Prieto, B. Conversion of a digital camera into a non-contact colorimeter for use in stone cultural heritage: The application case to Spanish granites. Meas. J. Int. Meas. Confed. 2014, 56, 194-202. [CrossRef]

39. Flamini, G.; Cioni, P.L.; Puleio, R.; Morelli, I.; Panizzi, L. Antimicrobial activity of the essential oil of Calamintha nepeta and its constituent pulegone against bacteria and fungi. Phyther. Res. 1999, 13, 349-351. [CrossRef]

40. Palazzi, S. Colorimetria: La Scienza del Colore Nell'arte e Nella Tecnica; Nardini: Fiesole, Italy, 1995; ISBN 88-404-4040-2. (In Italian)

41. Arantes, S.M.; Piçarra, A.; Guerreiro, M.; Salvador, C.; Candeias, F.; Caldeira, A.T.; Martins, M.R. Toxicological and pharmacological properties of essential oils of Calamintha nepeta, Origanum virens and Thymus mastichina of Alentejo (Portugal). Food Chem. Toxicol. 2019, 133, 110747. [CrossRef]

(C) 2020 by the authors. Licensee MDPI, Basel, Switzerland. This article is an open access article distributed under the terms and conditions of the Creative Commons Attribution (CC BY) license (http://creativecommons.org/licenses/by/4.0/). 